\title{
Assessing the impact of climate variability and human activities on streamflow variation
}

\author{
Jianxia Chang, Hongxue Zhang, Yimin Wang, and Yuelu Zhu \\ State Key Laboratory Base of Eco-hydraulic Engineering in Arid Area, Xi' an University of Technology, Xi' an 710048, China \\ Correspondence to: Jianxia Chang (chxiang@xaut.edu.cn)
}

Received: 29 September 2015 - Published in Hydrol. Earth Syst. Sci. Discuss.: 10 December 2015

Revised: 28 March 2016 - Accepted: 29 March 2016 - Published: 22 April 2016

\begin{abstract}
Water resources in river systems have been changing under the impact of both climate variability and human activities. Assessing the respective impact on decadal streamflow variation is important for water resource management. By using an elasticity-based method and calibrated TOPMODEL and VIC hydrological models, we quantitatively isolated the relative contributions that human activities and climate variability made to decadal streamflow changes in the Jinghe basin, located in the northwest of China. This is an important watershed of the Shaanxi province that supplies drinking water for a population of over 6 million people. The results showed that the maximum value of the moisture index $\left(E_{0} / P\right)$ was 1.91 and appeared in 1991-2000, and the decreased speed of streamflow was higher since 1990 compared with 1960-1990. The average annual streamflow from 1990 to 2010 was reduced by $26.96 \%$ compared with the multiyear average value (from 1960 to 2010). The estimates of the impacts of climate variability and human activities on streamflow decreases from the hydrological models were similar to those from the elasticity-based method. The maximum contribution value of human activities was $99 \%$ when averaged over the three methods, and appeared in 1981-1990 due to the effects of soil and water conservation measures and irrigation water withdrawal. Climate variability made the greatest contribution to streamflow reduction in 1991-2000, the values of which was $40.4 \%$. We emphasized various source of errors and uncertainties that may occur in the hydrological model (parameter and structural uncertainty) and elasticity-based method (model parameter) in climate change impact studies.
\end{abstract}

\section{Introduction}

Catchment hydrology and water resources are driven by climate and strongly modulated by human activities. Climate variability affects catchment streamflow, chiefly through precipitation and the variability of potential evaporation (Scanlon et al., 2007; Chien et al., 2013; Ward et al., 2009; Chang et al., 2010). Human activities include land use/cover change, reservoir operations, and direct water extraction from surface water and groundwater, all of which can alter river streamflow. It is important to separate and quantify the effects of climate variability and human activities so that they can be used for land use planning, water extraction and water resource management. With the increasing scarcity of water resources, hydrologists, decision makers, and policy makers have paid considerable attention to how much of the observed change in annual streamflow can be attributed to climate variability and human activities (Zhang et al., 2008; Tomer and Schilling, 2009; Roderick and Farquhar, 2011; Destouni et al., 2013).

Catchment experiments are very useful to determine the influence of vegetation change on the water balance; however, they are often limited to small scales. A number of catchment afforestation and deforestation studies have been conducted. Most of the results indicated that catchment streamflow significantly decreased after afforestation and increased after deforestation (Van Lill et al., 1980; Zhang et al., 2001; Tuteja et al., 2007). Two other main approaches, process based and statistic based, were generally used. The process-based method uses hydrological models to quantify the contribution of climate variability to streamflow change by varying the meteorological inputs for fixed land use/cover conditions (Xu et al., 2013; Petchprayoon et al., 2010; Lin et al., 2010; Tesfa et al., 2014; Zhang et al., 2012). Sta- 

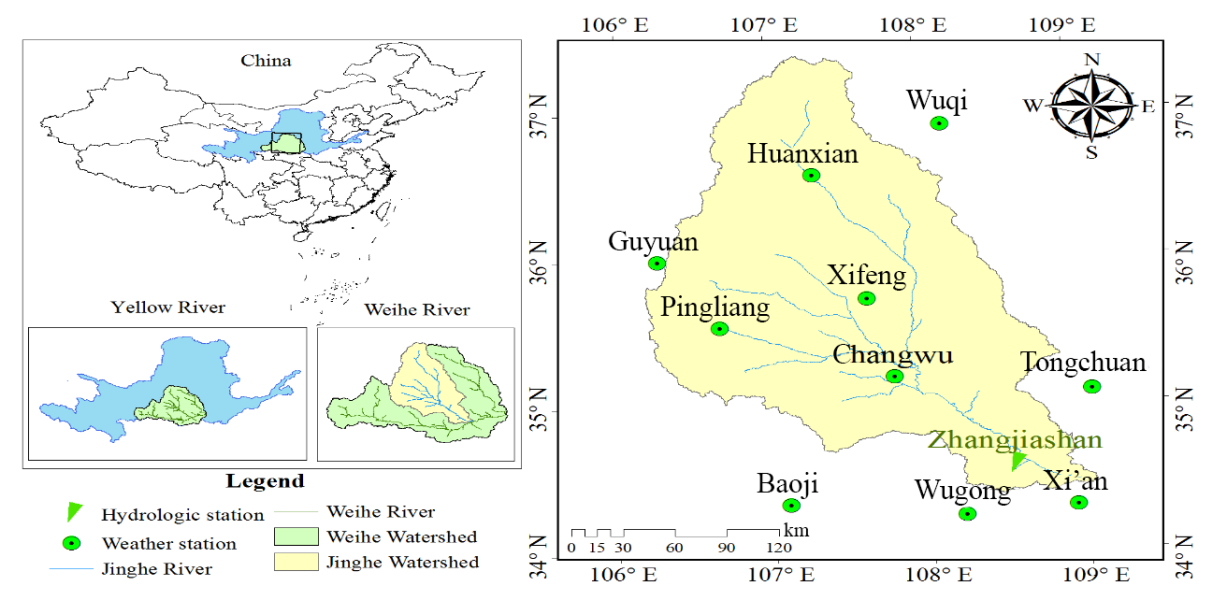

Figure 1. Location of hydrological and meteorological stations along the Jinghe River.

tistical methods for identifying the contributions of climate and human impacts on runoff were also used, especially in regions where long-term climate and hydrological data were available (Hamed, 2008; Notebaert et al., 2011; Renner et al., 2012; Roudier et al., 2014). Among the statistical methods, streamflow elasticity was commonly used to quantify the influence of changes in precipitation and potential evapotranspiration on streamflow (Sankarasubramanian et al., 2001; Chiew, 2006; Fu et al., 2007; Roderick and Farquhar, 2011). Streamflow elasticity can be obtained nonparametrically from observations or by employing a parametric model, such as the Budyko hypothesis or other models. The Budyko hypothesis was widely used, as it was an easy method with a limited requirement for climate data (Donohue et al., 2007; Liu et al., 2009; Wang and Hejazi, 2011; Wang et al., 2013).

Climate change and human activities have had tremendous impact on the water resources of China's highly urbanized regions. One such river basin is the Jinghe River, which is the secondary tributary of the Yellow River, the largest tributary of the Weihe River in China, with an area of $45400 \mathrm{~km}^{2}$ and an average annual natural streamflow of $12.3 \times 10^{8} \mathrm{~m}^{3}$. This is an important watershed of the Shaanxi province that supplies drinking water for a population of over 6 million people. The area is an important economic center of the Shaanxi province in China, and the water shortage became a bottleneck for economic progress. Human activities, such as water withdrawal, soil and water conservation projects, have become extensive in the Jinghe River during the last several decades. Climate change studies in the Yellow River basin reported warming trends at a rate of $1.28^{\circ} \mathrm{C}$ over 50 years, while the average precipitation dropped by approximately $8.8 \%$ over the second half of the 20th century (Yang et al., 2004). A combination of these effects reduced the streamflow (Gao et al., 2013; Chang et al., 2015). Few studies were devoted to using the methods of elasticity modeling together with hydrological modeling to quantitatively analyze the contributions of climate variability and human activities to streamflow variation in the Jinghe River basin.

The aims of this study were to (1) present a generic framework that investigate the impact of climate variability and human activities on streamflow using the concept of streamflow elasticity and hydrological models, the TOPMODEL and VIC models, which are fundamentally different in regard to their representation of streamflow generation and (2) compare these methods. The elasticity-based method only provides results at a mean annual timescale, whereas the hydrological modeling results are at a monthly and daily scale, and they are aggregated to the mean annual timescale for comparison with those obtained from the statistical method.

The Jinghe River basin (JRB) was chosen as the study area, which has presented a significantly decreasing trend of annual streamflow since 1990 (Chang et al., 2015; Du and Shi, 2012). This paper is organized as follows: Sect. 2 describes the study area and data sources; Sect. 3 is devoted to introducing the methods used; Sect. 4 provides hydrological modeling and the elasticity method results; Sect. 5 compares the results from the hydrological modeling with the elasticity-based method; and Sect. 6 discusses several conclusions generated from the present study.

\section{Study area and data}

The JRB $\left(106^{\circ} 14^{\prime}-109^{\circ} 06^{\prime} \mathrm{E}, 34^{\circ} 46^{\prime}-37^{\circ} 24^{\prime} \mathrm{N}\right)$ is located in semiarid area in China and is approximately $455 \mathrm{~km}$ long, with a drainage area of $45400 \mathrm{~km}^{2}$ (Fig. 1). The climate is temperate with cool, dry winters and hot summers, and the mean annual temperature is in the $7.8-13.5^{\circ} \mathrm{C}$ range across the basin. The mean annual precipitation is approximately $514 \mathrm{~mm}, 80 \%$ of which falls between June and October, and the mean annual potential evapotranspiration is $870 \mathrm{~mm}$. The precipitation and streamflow both have strong inter-annual and intra-annual variabilities. The seasonal variation of streamflow is similar to that of precipitation. The 
streamflow between July and October is approximately $65 \%$ of the mean annual streamflow. The Zhangjiashan station is the downstream hydrometric station on the main stream of the Jinghe River.

Human activities have become extensive in the JRB during the last several decades. Water withdrawal has increased rapidly due to the increase of the population, industry, and agricultural water demand. Thick and highly erodible loess, unevenly distributed rainfall, and the relatively high intensity of rainstorms have led to high soil loss rates across the basin. To reduce soil loss, soil and water conservation measures have been undertaken since the 1970s, which have resulted in an increase in vegetation cover. Therefore, climate variability combined with human activities has contributed to the decrease of the streamflow in the JRB (Chang et al., 2015; Du and Shi, 2012).

In this study, the catchment information data set, including the catchment boundary and runoff ratio, was from the Ministry of Water Resources of the People's Republic of China. The daily, monthly, and annual climate variables and observed streamflow were used. The daily meteorological data, including precipitation, air temperature, sunshine hours, relative humidity, and wind speed, of 10 stations during 19602010 were collected from the China Meteorological Administration. The monthly and annual precipitation was then established from the collected data, and annual maximum, annual minimum, and multiannual mean air temperature values were then calculated according to the daily data. The monthly potential evaporation was calculated according to the monthly wind speed, sunshine hours, relative humidity, and air temperature using the Penman-Monteith method. The daily streamflow data of the Zhangjiashan hydrological station for the same period were gathered from the Shaanxi Hydrometric and Water Resource Bureau. The DEM data were obtained from the SRTM $30 \mathrm{~m}$ digital elevation data. The soil data were extracted from the FAO two-layer $5 \mathrm{~min}$ 16-category global soil texture maps. Figure 1 also shows the location of the meteorological stations and hydrological station in the basin.

\section{Methodology}

\subsection{Framework of analysis}

The historic streamflow series can be split into two subseries according to the streamflow break year, and human activities in the recorded years prior to the break year can be negligible. The recorded years prior to this break year were defined as the baseline period, while the recorded years after this break year were defined as the changed period. The difference between the mean annual streamflow during the changed period $\left(Q_{2}\right)$ and the mean annual streamflow during the baseline period $\left(Q_{1}\right)$ represent the total change of the streamflow $(\Delta Q)$ after the break year. The $\Delta Q$ can be regarded as a function of climatic variables and the integrated effects of topography, soil, land use/cover and human activities, such as water withdrawal. Under the assumption that the topography and soil of the study area did not vary during the study period, $\Delta Q$ was referred to as a combination of climate variability and human activities and can be estimated as the formulation

$\Delta Q=Q_{2}-Q_{1}$,

where $\Delta Q$ is the total change in the mean annual streamflow, and $Q_{1}$ and $Q_{2}$ are the average annual streamflows before and after an abrupt change, respectively.

The total change in the mean annual streamflow can be estimated as

$\Delta Q=\Delta Q_{\mathrm{C}}+\Delta Q_{\mathrm{H}}$,

where $\Delta Q_{\mathrm{C}}$ and $\Delta Q_{\mathrm{H}}$ are the changes in the mean annual streamflow due to climate and human activities, respectively.

\subsection{Climate elasticity model for $\Delta Q_{\mathrm{C}}$}

The concept of streamflow elasticity was first introduced by Schaake (1990) to evaluate the sensitivity of streamflow to climate change. It represents the proportional change in streamflow divided by the proportional change in a climatic variable $(X)$, such as precipitation or potential evapotranspiration, and is expressed as

$\varepsilon=\frac{\partial Q / Q}{\partial X / X}$.

Thus, precipitation elasticity and evapotranspiration elasticity of streamflow were defined by Schaake (1990) as

$\varepsilon_{P}(P, Q)=\frac{\mathrm{d} Q / Q}{\mathrm{~d} P / P}=\frac{\mathrm{d} Q}{\mathrm{~d} P} \frac{P}{Q}$

$\varepsilon_{E_{0}}\left(E_{0}, Q\right)=\frac{\mathrm{d} Q / Q}{\mathrm{~d} E_{0} / E_{0}}=\frac{\mathrm{d} Q}{\mathrm{~d} E_{0}} \frac{E_{0}}{Q}$,

where $P, E_{0}$, and $Q$ are precipitation, potential evapotranspiration, and streamflow, respectively. $\varepsilon_{P}$ and $\varepsilon_{E_{0}}$ are the elasticity of streamflow with respect to $P$ and $E_{0}$, respectively. Changes in these factors could lead to streamflow variation, and the relationship can be estimated (Milly and Dunne, 2002) as

$\Delta Q_{\mathrm{C}}=\left(\varepsilon_{P} \Delta P / P+\varepsilon_{E_{0}} \Delta E_{0} / E_{0}\right) Q$,

where $\Delta P$ and $\Delta E_{0}$ are the changes in precipitation and potential evapotranspiration, respectively, and $\varepsilon_{P}+\varepsilon_{E_{0}}=1$. To estimate $\Delta Q_{\mathrm{C}}$ using Eq. (6), the estimate of the precipitation elasticity of streamflow $\varepsilon_{P}$ is needed. In this paper, the Budyko hypothesis was used to estimate $\varepsilon_{P}$.

The Budyko hypothesis (Yang et al., 2008; Teng et al., 2012; Wang et al., 2015) produces a simplified but powerful coupled water-energy balance method. It is a holistic approach that assumes that water balance is controlled 
by water availability and atmospheric demand. The water availability can be approximated by precipitation. The atmospheric demand represents the maximum possible evapotranspiration and is often equated with potential evapotranspiration. The role of the landscape properties on the mean annual water balance is mainly implicit and is deemed to be subservient to the dominant role of climate. In some formulations of the Budyko formulation, the role of the landscape is represented by a separate lumped parameter (Sun et al., 2014; Donohue et al., 2007), which is nevertheless estimated empirically. According to the long-term water balance equation $\left(Q=P-E_{\mathrm{a}}\right)$ and the Budyko hypothesis, the actual evapotranspiration $\left(E_{\mathrm{a}}\right)$ is a function of the aridity index $\left(\Phi=E_{0} / P\right)$ and the precipitation and potential evapotranspiration elasticity of streamflow can be expressed as (Arora, 2002; Dooge et al., 1999)

$\varepsilon_{P}=1+\varnothing F^{\prime}(\varnothing) /(1-F(\varnothing))$ and $\varepsilon_{P}+\varepsilon_{E_{0}}=1$.

A couple of mathematical functions were proposed to represent the Budyko hypothesis (e.g., Fu, 1996; Milly, 1993). We used the Budyko formulation of $\mathrm{Fu}$ (1981) who combined a dimensional analysis with mathematical reasoning and developed analytical solutions for the mean annual actual evapotranspiration

$F(\varnothing)=1+\varnothing-\left(1+\varnothing^{w}\right)^{1 / w}$,

where $F()$ is a function proposed by the Budyko, which not only satisfies the boundary conditions under the land surface evapotranspiration but also remains independent from the balance equation of hydrothermal coupling (the water balance and energy balance). $w$ is a model parameter with range $[1, \infty]$, which is related to vegetation type, soil hydraulic property, and topography (Fu, 1996). $w$ was set to 2.0, according to Li et al. (2013).

\subsection{Modeling-based approach for $\Delta Q_{\mathrm{C}}$ or $\Delta Q_{\mathrm{H}}$}

Hydrological models can also be used to assess the impact of climate change and human activities on streamflow. A hydrological model was calibrated and validated to estimate $\Delta Q_{\mathrm{C}}$ and $\Delta Q_{\mathrm{H}}$ by using the data from the baseline period. The model was run using climate data (e.g., precipitation and temperature) during the changed period with human activities (i.e., land use and management) and during the baseline period. $\Delta Q_{\mathrm{C}}$ was estimated as the difference between the mean annual average of simulated streamflow during the changed period and the mean annual average of simulated streamflow during the baseline period. $\Delta Q_{\mathrm{H}}$ was estimated as the difference between the mean annual average of the simulated streamflow during the changed period and the mean annual average of the observed streamflow during the changed period.

In this study, two hydrological models, the TOPMODEL and the VIC model, were used to investigate the effects of climate variability and human activities on streamflow. TOPMODEL (Beven and Kirkby, 1979) is a semidistributed variable contributing area hydrological model. It is based on simple physical reasoning and assumes that there is a steady transfer of water in the saturated zone along hillslopes, with a water table nearly parallel to the ground surface. It considers two streamflow sources: (shallow) groundwater and saturation overland flow. The model assumes an exponential decay of soil transmissivity with increasing water table depth, and it considers two main parameters for the dynamics of the saturated store: the recession parameter $m[L]$ and the average soil transmissivity at saturation $T\left[L T^{-1}\right]$. The classical form for the topographic index that follows from the exponential assumption, $\lambda_{i}=\ln (a / \tan b)$ was used, where $a$ is the drained area per unit length of the contour curve and $b$ is the topographic gradient. All of the points in the catchment with the same topographic index were predicted as having the same deficit, i.e., they were considered to be hydrologically similar. The original TOPMODEL had four parameters: the maximum allowable root storage deficit $\left(\mathrm{SR}_{\max }\right)$, the transmissivity of the soil in the saturated state $(T)$, the maximum moisture max deficit $\left(S_{\mathrm{zm}}\right)$, and the recharge delay parameter $\left(T_{\mathrm{d}}\right)$. Since the early $1990 \mathrm{~s}$, TOPMODEL has widely been applied to watersheds all over the world because it can provide spatially distributed hydrological information with available input requirements (e.g., Digital Elevation Model (DEM) data) (Seibert et al., 1997, Chen and Wu, 2012; Furusho et al., 2013). Some studies also applied TOPMODEL in semiarid area basins, such as the Yellow River in China, and the results showed that this model was applicable over a wide range of environments (Xiong and Guo, 2004; Boston et al., 2004; Gumindoga et al., 2014).

The VIC model is a large-scale hydrological model that was originally developed at the University of Washington (Liang et al., 1994; Grimson et al., 2013; Gao et al., 2011). The hydrological processes of the model include the interaction of the atmosphere with underlying vegetation and soils, where dynamic water and energy fluxes are considered. One distinguishing characteristic of the VIC model is that it represents the subgrid spatial heterogeneity of precipitation with the subgrid spatial variability of soil infiltration capacity. A variable infiltration curve is used to represent the subgrid variability of the soil infiltration capability under different land cover and soil types. Three types of potential evaporation are considered in the model: potential evaporation from the canopy layer of each vegetation class, transpiration from each of the vegetation classes, and bare soil potential evaporation. We used six parameters in the calibration of the VIC model. These included three baseflow parameters: $D m, W s$, and $D s$; the variable soil moisture capacity curve parameter $b$; and two parameters, $d 2$ and $d 3$, that controlled the thickness of the second and third soil layer, respectively. The VIC model was successfully applied to assess the impact of climate change on hydrology and water resources in China 

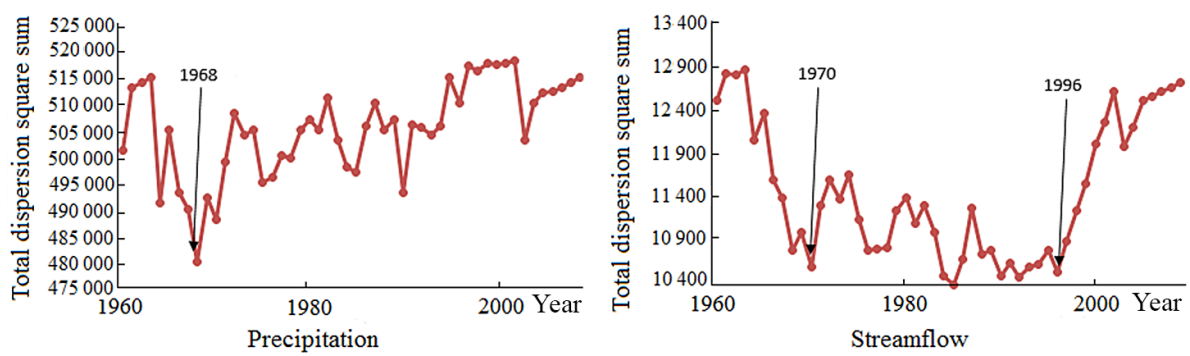

Figure 2. The abrupt change points of precipitation and streamflow in the JRB with sequential cluster.

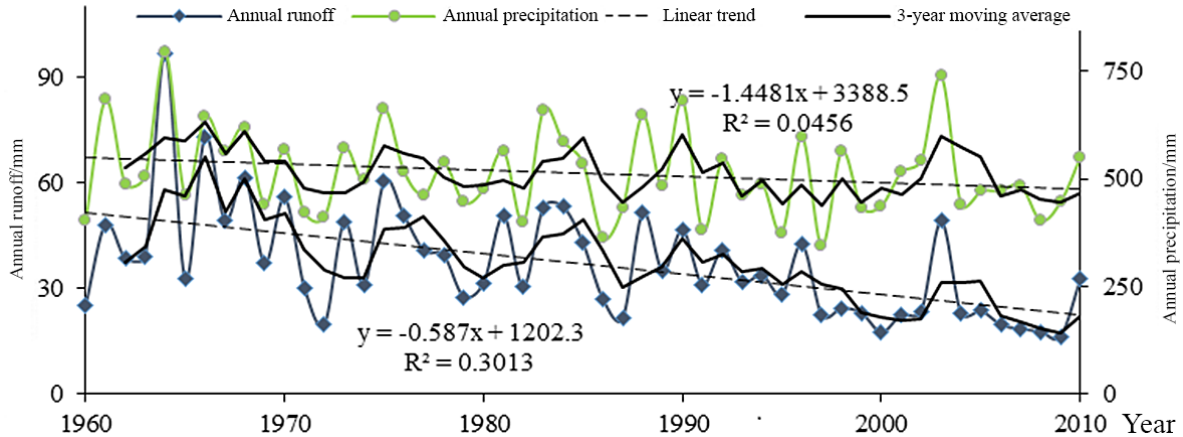

Figure 3. Changes of the annual streamflow and precipitation of the JRB.

(Wang et al., 2010; Bao et al., 2012; Su and Xie, 2003; Liu et al., 2013).

We obtained the break points of precipitation and streamflow series in the JRB by means of a sequential cluster analysis method, and the break points appeared in 1968 and 1970 (Fig. 2), respectively, so we used $1960-1970$ as the baseline period for this study. The TOPMODEL and the VIC model were calibrated using the historical data from 1960 to 1966 and validated against the observation during the period of 1967 to 1970. During the calibration, adjustments were made to minimize the sum of squares of the difference between the modeled and recorded monthly streamflow. Nash-Sutcliffe efficiency coefficients (NSE) and relative water balance error percentage (WBE) were used for the model assessment using the observed data and model estimates.

$\mathrm{NSE}=1-\frac{\sum_{i=1}^{N}\left(Q_{\mathrm{o}, i}-Q_{\mathrm{s}, i}\right)^{2}}{\sum_{i=1}^{N}\left(Q_{\mathrm{o}, i}-\overline{Q_{\mathrm{o}}}\right)^{2}}$

$\mathrm{WEB}=\left|\frac{100 \times\left(\sum_{i=1}^{N} Q_{\mathrm{s}, i}-\sum_{i=1}^{N} Q_{\mathrm{o}, i}\right)}{\sum_{i=1}^{N} Q_{\mathrm{o}, i}}\right|$

Here, $Q_{\mathrm{o}, i}$ is the observed streamflow of period $i, Q_{\mathrm{s}, i}$ is the simulated streamflow of period $i$, and $\overline{Q_{\mathrm{o}}}$ is the mean of observed streamflow.

\section{Results}

\subsection{The analysis of streamflow, precipitation, potential evaporation, and temperature}

The regional average precipitation, potential evaporation and temperature in the JRB during 1960-2010 were calculated using the Thiessen polygon method of ArcGIS 9.3, according to the corresponding data of 10 hydrometeorology stations.

The annual observed precipitation in the JRB and streamflow at the Zhangjiashan station both showed a statistically decreasing trend (Fig. 3), while the streamflow had a larger decrease. The values of the regression slope were -1.44 and -0.58 . The multiyear average streamflow (from 1960 to 2010 ) was $37.03 \mathrm{~mm}$, and the average annual streamflow was $43.47 \mathrm{~mm}$ from 1960 to 1990 , which meant that the streamflow from 1960 to 1990 increased by $17.39 \%$ compared with the multiyear average streamflow. The average annual streamflow was $27.05 \mathrm{~mm}$ during 1991-2010 and was reduced by $26.96 \%$ compared with the multiyear average value; therefore, the speed of the streamflow decrease was higher since 1990. The 3-year moving curve showed that precipitation and streamflow fluctuation was similar, which indicated that precipitation was the main source of streamflow. The statistical results of precipitation, streamflow, and the runoff coefficient in JRB are listed in Table 1. The maximums of precipitation and streamflow appeared at the same time in 1964; however, the minimum of precipitation and streamflow occurred in different years (1997 and 2009), which resulted 
Table 1. Characteristics of the inter-annual streamflow and precipitation of the JRB.

\begin{tabular}{|c|c|c|c|c|c|c|c|c|c|c|}
\hline \multirow[t]{2}{*}{ Feature } & \multirow[t]{2}{*}{ Mean } & \multirow[t]{2}{*}{ Wet year } & \multicolumn{2}{|c|}{ Maximum } & \multicolumn{2}{|c|}{ Minimum } & \multirow{2}{*}{$\begin{array}{r}\text { Extremes } \\
\text { ratio } \\
C_{v}\end{array}$} & \multirow{2}{*}{$\begin{array}{r}\text { Variation } \\
\text { coefficient } \\
(\mathrm{mm})\end{array}$} & \multirow{2}{*}{$\begin{array}{r}\text { Flood } \\
\text { period } \\
(\%)\end{array}$} & \multirow{2}{*}{$\begin{array}{r}\text { Dry } \\
\text { period } \\
(\%)\end{array}$} \\
\hline & & & time & value & time & value & & & & \\
\hline Precipitation & $514(\mathrm{~mm})$ & $613.11(\mathrm{~mm})$ & 1964 & $794(\mathrm{~mm})$ & 1997 & $343(\mathrm{~mm})$ & 2.31 & 0.20 & 64.21 & 7.46 \\
\hline Streamflow & $.51(\mathrm{~mm})$ & $66.80(\mathrm{~mm})$ & 1964 & $85.46(\mathrm{~mm})$ & 2009 & $7.09(\mathrm{~mm})$ & 12.05 & 0.48 & 66.8 & 18.22 \\
\hline Runoff coefficient & 0.05 & 0.08 & 1964 & 0.12 & 2009 & 0.04 & 3.34 & 0.28 & - & - \\
\hline Flood runoff coefficient & 0.06 & - & 1964 & 0.12 & 2007 & 0.03 & 3.86 & 0.33 & - & - \\
\hline
\end{tabular}

Table 2. The average monthly estimated potential evaporation and temperature value of the JRB from 1960 to 2010.

\begin{tabular}{|c|c|c|c|c|c|c|c|c|c|c|c|c|}
\hline Month & Mar & Apr & May & Jun & Jul & Aug & Sep & Oct & Nov & Dec & Jan & Feb \\
\hline$E_{0}(\mathrm{~mm})$ & 61 & 90 & 118 & 131 & 126 & 108 & 70 & 49 & 32 & 24 & 26 & 34 \\
\hline Mean $(\mathrm{mm})$ & \multicolumn{3}{|c|}{90 (Spring) } & \multicolumn{3}{|c|}{122 (Summer) } & \multicolumn{3}{|c|}{50 (Autumn) } & \multicolumn{3}{|c|}{28 (Winter) } \\
\hline $\begin{array}{l}T\left({ }^{\circ} \mathrm{C}\right) \\
\text { Mean }\left({ }^{\circ} \mathrm{C}\right)\end{array}$ & 4.1 & $\begin{array}{l}10.7 \\
10.2\end{array}$ & 15.8 & 20 & $\begin{array}{l}21.8 \\
20.7\end{array}$ & 20.3 & 15.2 & $\begin{array}{l}9.2 \\
8.9\end{array}$ & 2.4 & -3.3 & $\begin{array}{l}-4.7 \\
-3.3\end{array}$ & -1.7 \\
\hline
\end{tabular}

Note: $E_{0}$ was the potential evaporation; $T$ was the temperature.

Table 3. Statistical values of the potential evaporation and temperature of the JRB from 1960 to 2010.

\begin{tabular}{lrrrrrrr}
\hline \multirow{2}{*}{ Feature } & Mean & $C_{v}$ & $C_{\mathrm{S}}$ & \multicolumn{2}{c}{ Maximum } & \multicolumn{2}{c}{ Minimum } \\
\cline { 5 - 8 } & & & & time & value & time & value \\
\hline$E_{0}$ & $870(\mathrm{~mm})$ & 0.08 & 0.53 & 2004 & $1092(\mathrm{~mm})$ & 1964 & $713(\mathrm{~mm})$ \\
$T$ & $9.1\left({ }^{\circ} \mathrm{C}\right)$ & 0.07 & 0.09 & 1998 & $10.2\left({ }^{\circ} \mathrm{C}\right)$ & 1967 & $7.6\left({ }^{\circ} \mathrm{C}\right)$ \\
\hline
\end{tabular}

Note: the mean was the multiyear average value; $C_{v}$ was the deviation coefficient; $C_{\mathrm{s}}$ was the skewness coefficient.
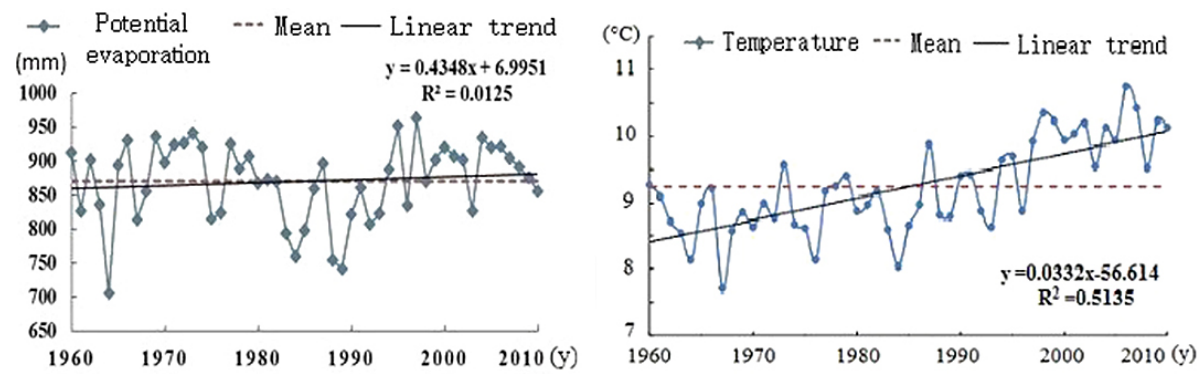

Figure 4. Changes of the annual potential evaporation and temperature of the JRB.

from water withdrawal and other reasons, such as changes in groundwater. The precipitation and streamflow during the flood season (from July to October) accounted for 64.21 and $66.80 \%$, respectively, and the proportion of the dry period (from November to March of next year) was 7.46 and $18.22 \%$, respectively. The proportion of precipitation that became runoff was low, with a mean annual runoff ratio of 0.05 , but increased during the wet years. The runoff ratios during the wet year and wet season were 0.08 and 0.06 , respectively.

The result of Mann-Kendall's test showed the same decreasing trend for the annual precipitation and streamflow in
JRB from 1960 to 2010 . The $Z$ value of streamflow and precipitation was -4.26 (confidence level was $99 \%$ ) and -1.39 (confidence level was $90 \%$ ), respectively, which meant that the decreasing trend for streamflow was significant, but was insignificant for precipitation at $a=0.05$ level.

Table 2 shows the monthly and seasonal potential evaporation and temperature in the JRB, which indicated that the potential evaporation $(122 \mathrm{~mm})$ and temperature $\left(20.7^{\circ} \mathrm{C}\right)$ in summer were much higher than the other three seasons, and the maximum values for the potential evaporation and temperature appeared in June and July, respectively. The interannual variation and characteristic values of the potential 
Table 4. The impact of climate variability and human activities on streamflow with the climate elasticity model.

\begin{tabular}{lrrrrrrrrrrrrrrr}
\hline Period & $\begin{array}{r}E_{0} \\
(\mathrm{~mm})\end{array}$ & $\begin{array}{r}P \\
(\mathrm{~mm})\end{array}$ & $\begin{array}{r}Q \\
\left(10^{8} \mathrm{~m}^{3}\right)\end{array}$ & $\begin{array}{r}\text { Aridity } \\
\text { index }\end{array}$ & $\begin{array}{r}\Delta E_{0} \\
(\mathrm{~mm})\end{array}$ & $\begin{array}{r}\Delta P \\
(\mathrm{~mm})\end{array}$ & $\begin{array}{r}\Delta Q \\
\left(10^{8} \mathrm{~m}^{3}\right)\end{array}$ & & & & & & & &
\end{tabular}

evaporation and temperature are shown in Fig. 4 and Table 3. The mean annual potential evaporation in the $1980 \mathrm{~s}$ (822 $\mathrm{mm})$ decreased compared with the values from the $1960 \mathrm{~s}(861 \mathrm{~mm})$ and started to increase slowly in the $1990 \mathrm{~s}$ (973 $\mathrm{mm})$. The temperature showed a slight upward trend in the 1970s and 1980s and had a sharp upward trend in the 1990 s era. The $Z$ values of potential evaporation and temperature for Mann-Kendall's test were 0.4 and 4.12, respectively, which meant that the potential evaporation presented an insignificant increasing trend, but the temperature had a significant increasing trend.

\subsection{Climate elasticity model results}

To assess the impact of climate variability on streamflow, the climate elasticity of streamflow was calculated using Eqs. (3)-(8) based on the annual precipitation and annual potential evapotranspiration of the period from 1971 to 2010. Table 4 summarizes the annual precipitation $(P)$, potential evapotranspiration $\left(E_{0}\right)$, precipitation elasticity $\left(\varepsilon_{P}\right)$, evapotranspiration elasticity $\left(\varepsilon_{E_{0}}\right)$ of streamflow for different periods, and percentage change in streamflow results for different periods when using the elasticity-based approaches. The variation of $\varepsilon_{P}$ was between 1.45 and 1.52 , while the variation of $\varepsilon_{E_{0}}$ was between -0.45 and -0.52 . As shown in Table 4, for the period of 1971 to 2010 , the values of $\varepsilon_{P}$ and $\varepsilon_{E_{0}}$ obtained were 1.48 and -0.48 , respectively. The results indicated that a $10 \%$ decrease in precipitation would result in a $14.8 \%$ drop in streamflow, while a $10 \%$ decrease in potential evapotranspiration would induce a $4.8 \%$ increase of streamflow. According to Eq. (3), with the calculated $\varepsilon_{P}$ and $\varepsilon_{E_{0}}$, it was estimated that the $60.1 \mathrm{~mm}$ decrease in precipitation in 1971-2010 might have decreased the streamflow by $40.9 \mathrm{~mm}$; meanwhile, the $7.3 \mathrm{~mm}$ increase in the potential evapotranspiration may have caused a $5.1 \mathrm{~mm}$ decrease in streamflow.

The reductions in streamflow from 1971 to 2010 due to climate variability ranged between 7.5 and $29.9 \%$, with a median of $19.3 \%$, for the JRB when using the Budyko framework method. The maximum and minimum values of the moisture index $\left(E_{0} / P\right.$, Willmott et al., 2011; Willmott and Feddema, 1992) were 1.91 and 1.53 , respectively, and appeared in 1991-2000 and 1981-1990, respectively. Com- pared with the 1960-1970 baseline period, the reductions in $\Delta Q$ for 1991-2000 and 1981-1990 were $5.7 \times 10^{8} \mathrm{~m}^{3}$ and $4.0 \times 10^{8} \mathrm{~m}^{3}$, respectively, with climate variability making the greatest and smallest contributions (i.e., 29.9 and $7.5 \%$, see Table 4).

\subsection{Hydrological model calibration and validation}

During the hydrological model simulation, the digital elevation quadrangles at a $30 \mathrm{~m}$ resolution in the study area were used (Fig. 5). In TOPMODEL, several sub-basins were delineated according to the flow accumulation by means of ArcGIS, and the flow direction and accumulation were extracted in ArcGIS to calculate the topographic index-area ratio of sub-basin. The monthly precipitation, potential evapotranspiration and observed streamflow acted as the input data. Figure 6 shows the simulated and recorded streamflow for the calibration and validation periods. A calibrated VIC model was also employed to separate the hydrological impacts of land use change and climate change. The VIC model was used for the streamflow simulation at a $0.5^{\circ}$ spatial and daily temporal resolution in the JRB (Fig. 5). Figure 6 shows the simulated and observed streamflows for the calibration and validation periods, with outputs computed on a monthly basis.

In the scatter plots in Fig. 7, the observed monthly streamflow was plotted along the $x$ axis, and the model simulated streamflows (calibration and validation) were plotted along the $y$ axis. The scatter plots in Fig. 7 showed that both the hydrological models performed reasonably well in the model calibration with high NSE values and low WBE values. The correlation of the simulated streamflow and measured streamflow $(R)$ was higher during the calibration period compared with the validation period. The observed and simulated streamflow over the noncalibration period were compared to determine the suitability of the model for this study. The NSE, WBE, and $R$ of TOPMODEL are 0.79 , $2.1 \%$, and 0.987 in the calibration period, and are, respectively, $0.78,9.2 \%$, and 0.944 in the validation period. The NSE, WBE, and $R$ of the VIC model are $0.77,3.5 \%$, and 0.944 in the calibration period, and are respectively 0.83 , $4.7 \%$, and 0.940 in the validation period. The NSE, WBE, and $R$ values during the validation period (see Fig. 7) sug- 


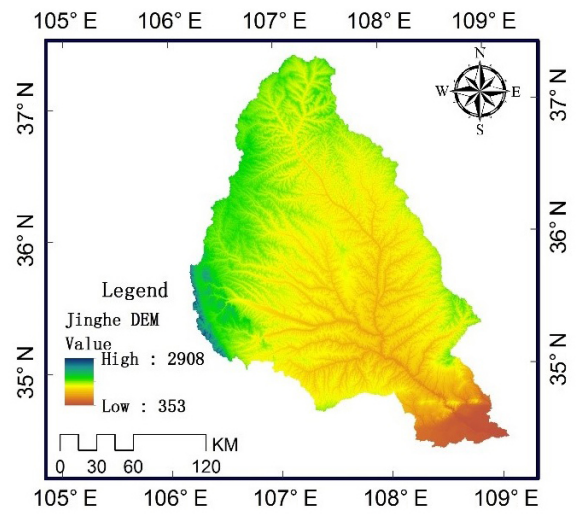

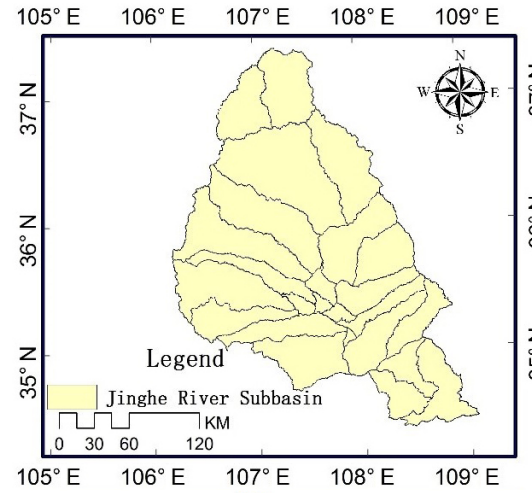

(b)

(a)

Figure 5. (a) Elevation maps of the study area at a $30 \mathrm{~m}$ resolution. (b) Sub-basin of TOPMODEL. (c) Grid of the VIC model.

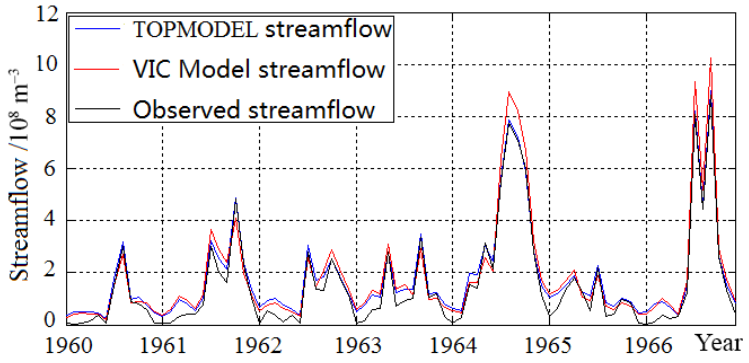

(a)

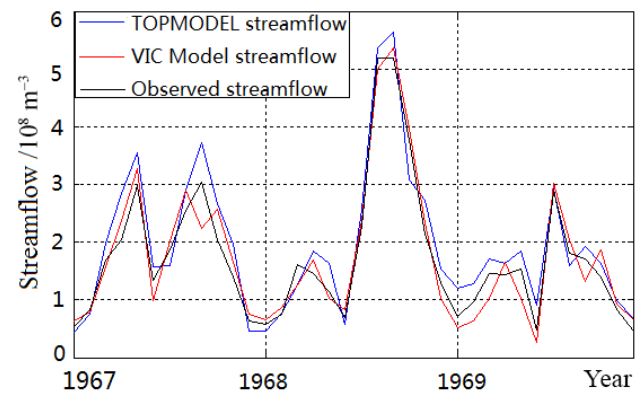

(b)

Figure 6. The simulated and observed streamflow for TOPMODEL and the VIC model. (a) Calibration period. (b) Validation period. gested that both the rainfall-runoff models and the calibration method used in this study were robust for the calibrated model to be used over an independent simulation period adequately. Additionally, the results justified the suitability of the models applied for assessing the change in streamflow due to climate variability and human activities.

\subsection{Hydrological model simulation results}

The calibrated model parameters for both the models from the baseline periods of 1960 to 1970 were used with the meteorological time series to simulate the streamflow for the changed period of 1971 to 2010 and to investigate the effects of climate variability and human activities. The scatter plots in Figs. 8 and 9 show the comparison of the simulated and observed monthly and annual streamflow time series for the JRB for the entire modeling period (1971-2010) for TOPMODEL and the VIC model, respectively.

The model simulation results showed that streamflow had a strong response to the environmental change after 1970. In the scatter plots in Fig. 8, the simulated monthly streamflow values are mostly above the $1: 1$ line, indicating that the simulated streamflow was much higher than the observed streamflow for most of the months. The amount of time that the simulated streamflow was higher than the ob- 


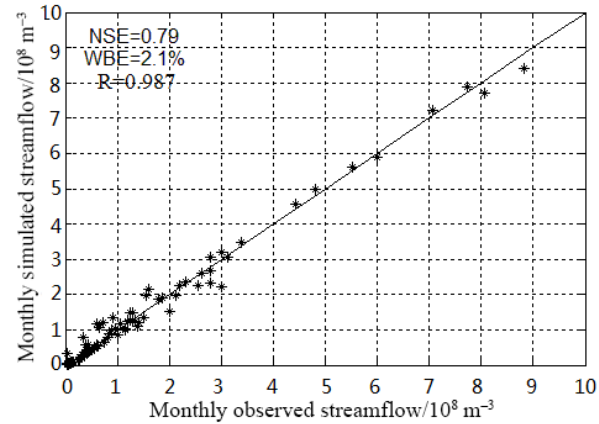

(a)

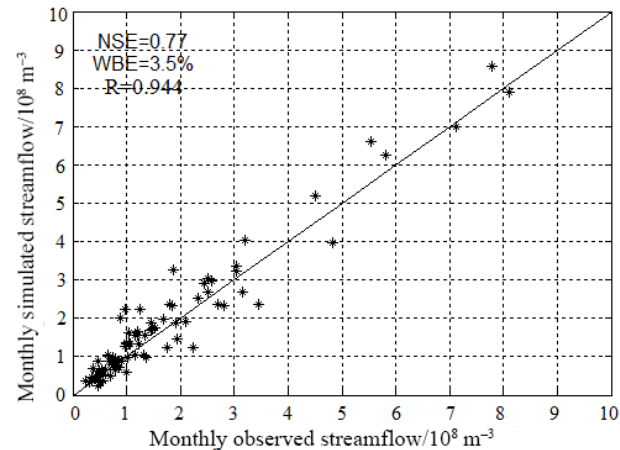

(c)

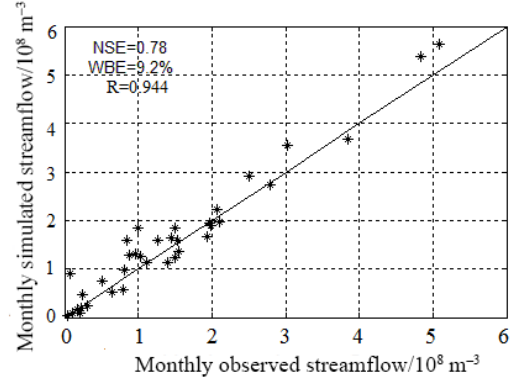

(b)

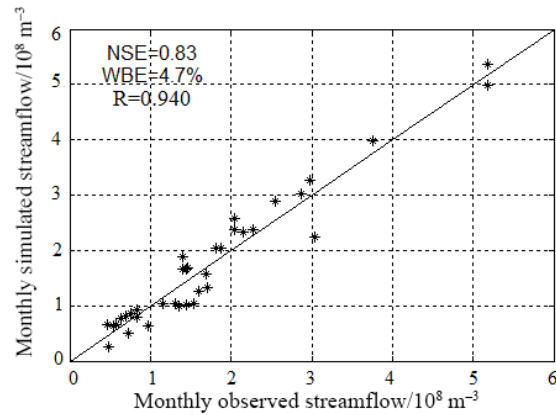

(d)

Figure 7. Comparison of the observed and modeled monthly streamflows for the calibration and validation periods. (a,b) Calibration and validation streamflow for TOPMODEL. (c,d) Calibration and validation streamflow for the VIC model.

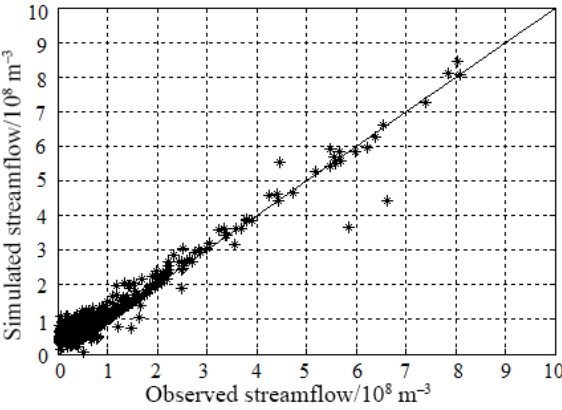

(a)

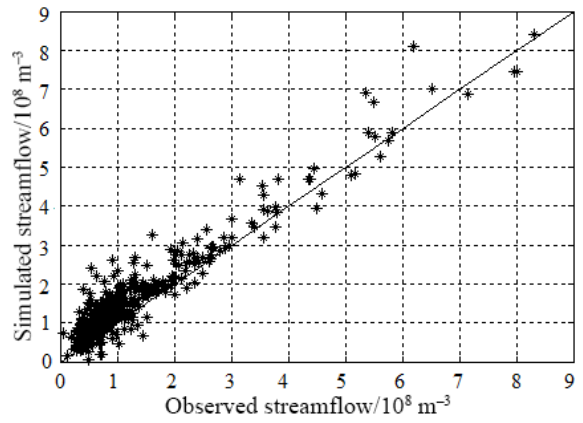

(b)

Figure 8. Comparison of the observed and modeled monthly streamflow in 1971-2010. (a) TOPMODEL. (b) The VIC model.

served streamflow was 26 years, from 1970 to 2010, for TOPMODEL, and 25 years for the same period for the VIC model. Additionally, most of the years appeared before 1990 or after 2005 for both of the models, and in the rest of the years the simulated streamflow was similar or lower to the observed value. The effect of climate variability was eliminated from the simulations for the changed periods by using the actual observed climate to drive the calibrated models. The difference in the observed and simulated streamflows during the changed period was due to the difference in land cover and other human activities. The results indicated that human activities caused significant reductions in streamflow, and these results were consistent with other studies (Chang et al., 2015; Tang et al., 2013; Zhan et al., 2014).

\subsection{Influence of human activities and climate variability}

To separate and quantify the effects of human activities on streamflow after 1970, the simulated streamflows for the two models were compared against the observed values during the baseline and changed periods (methodology details in Sect. 3.1). The differences in the observed streamflow values during the baseline and changed periods were caused by the differences in climatic conditions and human activi- 
Table 5. The impact of climate variability and human activities on streamflow with TOPMODEL.

\begin{tabular}{lrrrrrrr}
\hline Period & $Q_{\mathrm{B}}$ & \multicolumn{2}{c}{ Annual mean streamflow } & \multicolumn{2}{c}{ Human activities } & \multicolumn{2}{c}{ Climate variation } \\
& $\left(10^{8} \mathrm{~m}^{3}\right)$ & $\Delta Q\left(10^{8} \mathrm{~m}^{3}\right)$ & $Q_{\mathrm{S}}\left(10^{8} \mathrm{~m}^{3}\right)$ & $\Delta Q_{\mathrm{H}}\left(10^{8} \mathrm{~m}^{3}\right)$ & $\eta_{\mathrm{H}}(\%)$ & $\Delta Q_{\mathrm{C}}\left(10^{8} \mathrm{~m}^{3}\right)$ & $\eta_{\mathrm{C}}(\%)$ \\
\hline $1960-1970$ & 18.3 & - & - & - & - & - & - \\
$1971-1980$ & 11.4 & -6.9 & 17.0 & -5.6 & 81.2 & -1.3 & 18.8 \\
$1981-1990$ & 14.3 & -4.0 & 18.1 & -3.8 & 95 & -0.2 & 5 \\
$1991-2000$ & 12.6 & -5.7 & 15.6 & -3.0 & 52.6 & -2.7 & 47.4 \\
$2001-2010$ & 10.9 & -7.4 & 17.0 & -6.1 & 82.4 & -1.3 & 17.6 \\
$1971-2010$ & 12.3 & -6.0 & 16.9 & -4.6 & 76.7 & -1.4 & 23.3 \\
\hline
\end{tabular}

Table 6. The impact of climate variability and human activities on streamflow with the VIC model.

\begin{tabular}{lrrrrrrr}
\hline Period & $Q_{\mathrm{B}}$ & \multicolumn{2}{c}{ Annual mean streamflow } & \multicolumn{2}{c}{ Human activities } & \multicolumn{2}{c}{ Climate variation } \\
& $\left(10^{8} \mathrm{~m}^{3}\right)$ & $\Delta Q\left(10^{8} \mathrm{~m}^{3}\right)$ & $Q_{\mathrm{S}}\left(10^{8} \mathrm{~m}^{3}\right)$ & $\Delta Q_{\mathrm{H}}\left(10^{8} \mathrm{~m}^{3}\right)$ & $\eta_{\mathrm{H}}(\%)$ & $\Delta Q_{\mathrm{C}}\left(10^{8} \mathrm{~m}^{3}\right)$ & $\eta_{\mathrm{C}}(\%)$ \\
\hline $1960-1970$ & 18.3 & - & - & - & - & - & - \\
$1971-1980$ & 11.4 & -6.9 & 17.1 & -5.7 & 82.6 & -1.2 & 17.4 \\
$1981-1990$ & 14.3 & -4.0 & 18.8 & -4.5 & 112.5 & 0.5 & -12.5 \\
$1991-2000$ & 12.6 & -5.7 & 15.8 & -3.2 & 56.1 & -2.5 & 43.9 \\
$2001-2010$ & 10.9 & -7.4 & 16.7 & -5.8 & 78.4 & -1.6 & 21.6 \\
$1971-2010$ & 12.3 & -6.0 & 17.0 & -4.7 & 78.3 & -1.3 & 21.7 \\
\hline
\end{tabular}

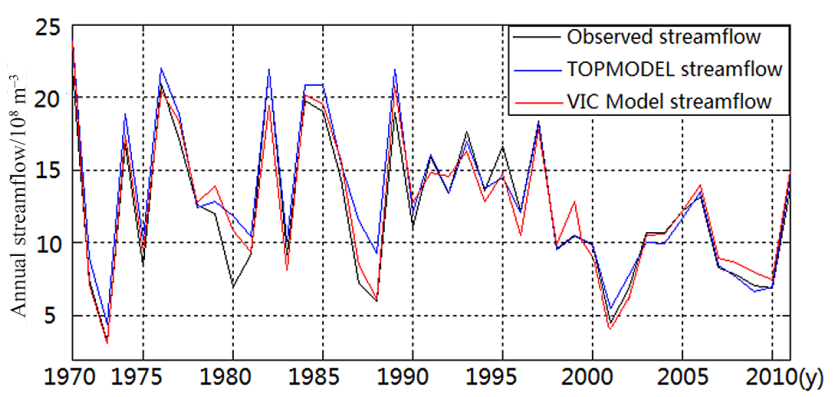

Figure 9. Time series of the observed and modeled annual streamflow for the entire modeling period.

ties. Tables 5 and 6 summarize the mean annual statistics of the observed and simulated streamflow for the different periods of the 1970s, 1980s, 1990s, and 2000s. The third column provides the values for $\Delta Q$, which were the differences between the observed streamflow $\left(Q_{\mathrm{B}}\right)$ during the changed periods and the baseline. The fourth column shows the simulated streamflow $\left(Q_{\mathrm{S}}\right)$ for the changed periods when using climate and calibrated parameter values from the baseline period. $\Delta Q_{\mathrm{H}}$ was the difference between $Q_{\mathrm{B}}$ and $Q_{\mathrm{S}}$ for the changed periods, and $\Delta Q_{\mathrm{C}}$ was the difference between $Q_{\mathrm{S}}$ for the changed period and $Q_{\mathrm{B}}$ of the baseline. $\eta_{\mathrm{C}}$ and $\eta_{\mathrm{H}}$ were the contribution ratios of climate change and human activities to streamflow, respectively.

The results showed that the average annual streamflow for 1971-2010 $\left(12.3 \times 10^{8} \mathrm{~m}^{3}\right)$ was less than that of the baseline period $\left(18.3 \times 10^{8} \mathrm{~m}^{3}\right)$, which meant that the recorded streamflow in the JRB markedly decreased over the past few decades. The total reduction $\Delta Q$ in streamflow for the changed period of 1971 to 2010 (compared to the baseline period) due to human activities and climate variability for the JRB were $4.6 \times 10^{8} \mathrm{~m}^{3}$ and $1.4 \times 10^{8} \mathrm{~m}^{3}$ for the TOPMODEL, which was approximately 76.7 and $23.3 \%$ of the total reduction, respectively. The corresponding reductions were $4.7 \times 10^{8} \mathrm{~m}^{3}(78.3 \%)$ and $1.3 \times 10^{8} \mathrm{~m}^{3}(21.7 \%)$ for the VIC model.

For the different periods of 1970s, 1980s, 1990s, and 2000 s, the reductions in streamflow due to human activities were $5.6 \times 10^{8} \mathrm{~m}^{3}\left(81.2 \%\right.$ of the total change), $3.8 \times 10^{8} \mathrm{~m}^{3}$ (95\% of the total change), $3.0 \times 10^{8} \mathrm{~m}^{3}(52.6 \%$ of the total change), and $6.1 \times 10^{8} \mathrm{~m}^{3}(82.4 \%$ of the total change) for TOPMODEL model, respectively. For the VIC model, the reductions in streamflow due to human activities for the $1970 \mathrm{~s}, 1980 \mathrm{~s}, 1990 \mathrm{~s}$, and $2000 \mathrm{~s}$ were and $5.7 \times 10^{8} \mathrm{~m}^{3}$ (82.6\% of the total change), $4.5 \times 10^{8} \mathrm{~m}^{3}(112.5 \%$ of the total change), $3.2 \times 10^{8} \mathrm{~m}^{3}$ (56.1\% of the total change), and $5.8 \times 10^{8} \mathrm{~m}^{3}(78.4 \%$ of the total change), respectively. Compared to the baseline period of 1960 to 1970, streamflow greatly decreased during 2001-2010. The change impacts (i.e., $\Delta Q_{\mathrm{H}}$ and $\Delta Q_{\mathrm{C}}$ ) in 2001-2010 were approximately $77.4 \%\left(\Delta Q_{\mathrm{H}}\right)$ and $22.6 \%\left(\Delta Q_{\mathrm{C}}\right)$ of the total reduction when averaged over the two methods.

\section{Discussion}

\subsection{Results of comparing the three methods}

We used elasticity-based analyses, TOPMODEL and the VIC model, to isolate the hydrological impact of human activi- 
ties from that of climate variability. The climate elasticity method is relatively simple and can easily be transplanted to other areas, and it provides a general streamflow change with less data and parameters (Ma et al., 2010). On the contrary, the hydrological modeling method more precisely distinguishes the streamflow change, such as the monthly change or daily change. In this paper, the three methods were implemented independently at different timescales (climate elasticity method based on the yearly scale, TOPMODEL based on the monthly scale and the VIC model hydrological simulation based on the daily scale (Peng and $\mathrm{Xu}, 2010)$. For the whole JRB, the contribution ratios of climate variability in 1971-2010 were 23.3, 21.7, and $19.3 \%$ from TOPMODEL, the VIC hydrological modeling method, and the elasticity method, respectively, and the mean contribution ratio was $21.4 \%$. The most significant climate variability impacts were $2.7 \times 10^{8} \mathrm{~m}^{3}(47.4 \%), 2.5 \times 10^{8} \mathrm{~m}^{3}$ $(43.9 \%)$, and $1.7 \times 10^{8} \mathrm{~m}^{3}$ (29.9\%) for TOPMODEL, the VIC model and the elasticity-based model, respectively, appearing in the 1990s. The most significant human activities impacts were $3.8 \times 10^{8} \mathrm{~m}^{3}(95 \%), 4.5 \times 10^{8} \mathrm{~m}^{3}(112.5 \%)$ and $3.7 \times 10^{8} \mathrm{~m}^{3}(92.4 \%)$ for TOPMODEL, the VIC model, and the elasticity-based model, respectively, appearing in the 1980s. The analysis showed that the results from the two hydrological models were similar to those from the commonly used elasticity-based approach. Additionally, the results of the three methods showed that the significant climate variability impacts appeared in the 1990s, and the significant human activities impacts appeared in the 1980s. The precipitation and temperature are the dominant factors of climate changes, and it is shown that the maximum decrease of precipitation appeared in the 1990s, compared with the baseline period (1960s), and the minimum decrease was in the 1980s (Table 7). The temperature showed a significant increase in the 1990s, but an insignificant increase in the 1980s. The changes of precipitation and temperature for different decades verified that the significant climate variability impacts appeared in the 1990s. We concluded that the three methods were in good agreement in terms of the dominant contributor, i.e., human activities played a more important role in the streamflow decrease than the change in climate in the JRB. The main result of this research agreed with the findings of other studies in northwest China. Tang et al. (2013) used the climate elasticity method and the Soil and Water Assessment Tool (SWAT) model to evaluate the impact of climate variability on streamflow in the Yellow River basin, these two methods gave consistent results. Zhan et al. (2014) developed an improved climate elasticity method based on the original climate elasticity method and conducted a quantitative assessment of the impact of climate change and human activities on the streamflow decrease in the Wei River basin. The results from the improved climate elasticity method yielded a climatic contribution to the streamflow decrease of 22-29\% and a human contribution of $71-78 \%$.
Table 7. Changes of the inter-annual precipitation and temperature of the JRB.

\begin{tabular}{lrrrr}
\hline Time & $\begin{array}{r}\text { Precipitation } \\
(\mathrm{mm})\end{array}$ & $\begin{array}{r}\text { Temperature } \\
\left({ }^{\circ}\right)\end{array}$ & $\begin{array}{r}\Delta P \\
(\mathrm{~mm})\end{array}$ & $\begin{array}{r}\Delta T \\
\left({ }^{\circ}\right)\end{array}$ \\
\hline $1960 \mathrm{~s}$ & 561.2 & 8.6 & - & - \\
$1970 \mathrm{~s}$ & 500.1 & 8.8 & -61.1 & 0.2 \\
$1980 \mathrm{~s}$ & 535.5 & 8.8 & -25.6 & 0.2 \\
$1990 \mathrm{~s}$ & 462.4 & 9.4 & -98.8 & 0.8 \\
$2000 \mathrm{~s}$ & 506.5 & 9.8 & -54.6 & 1.2 \\
\hline
\end{tabular}

Note: $\Delta P$ and $\Delta T$ are the changes in precipitation and temperature, respectively.

There are still differences in terms of the magnitude of each attributor. Compared to the results of the hydrological model, TOPMODEL, and the VIC model, the streamflow variation caused by climate variability estimated from the elasticity-based methods was smaller and that caused by human activities was larger, which agreed with the results of Li et al. (2012) and Sun et al. (2014). Except for the annual precipitation change, which was the most important factor in the streamflow change, the inter-annual and intra-annual precipitation variability, as second-order climate effects, could lead to a significant change in streamflow. However, these second-order climate effects cannot be taken into account in the elasticity-based methods, while they can be considered in the dynamic hydrological modeling method, which may partially explain the difference in the results (Potter and Chiew, 2011).

\subsection{Errors and uncertainties with each approach}

The elasticity-based assessment of environmental change on streamflow has more advantages than the hydrological modeling approach because it does not require detailed spatial input data. In this paper, the elasticity coefficient (i.e., the sensitivity coefficient of streamflow to climatic variable changes) was estimated. While it was commonly suggested that catchment properties were spatially and temporally varied and were influential on the streamflow of the watershed (Roderick and Farquhar, 2011; Donohue et al., 2011), the errors from both the model structure (Budyko equations) and the model parameter in Fu's model $(w)$, which we assumed to be temporally consistent, caused the elasticity-based analysis to not be free of error.

For the hydrological model of TOPMODEL and the VIC model, due to the errors of the model structure, input time series, and initial and boundary conditions, the predictions of physically based distributed models commonly contained a certain degree of uncertainty. For example, the higher resolution of the DEM (digital elevation model), the smaller input time series scale and the optimal model parameters would obtain better simulated results. 
Table 8. Cumulative area $\left(\mathrm{km}^{2}\right)$ of soil and water conservation in the JRB at the end of different years.

\begin{tabular}{lrrrrr}
\hline Period & $\begin{array}{r}\text { Level } \\
\text { terrace }\end{array}$ & Afforestation & $\begin{array}{r}\text { Grass } \\
\text { planting }\end{array}$ & $\begin{array}{r}\text { Check } \\
\text { dam }\end{array}$ & $\begin{array}{r}\text { Total } \\
\text { Total }\end{array}$ \\
\hline $1960 \mathrm{~s}$ & 50 & 184 & 11 & 4 & 249 \\
$1970 \mathrm{~s}$ & 330 & 666 & 90 & 10 & 1096 \\
$1980 \mathrm{~s}$ & 729 & 1520 & 169 & 18 & 2436 \\
$1990 \mathrm{~s}$ & 2356 & 4135 & 1023 & 49 & 7563 \\
$2000 \mathrm{~s}$ & 2907 & 4773 & 1146 & 52 & 8878 \\
\hline
\end{tabular}

\subsection{The cause for streamflow change}

The results indicated that human activities were the dominant factors (approximately $80 \%$ ) for the streamflow decrease in 1971-2010 in the study area. There were several types of human activities that influenced streamflow, including water conservancy projects, large hydraulic projects, and water withdrawal for industry and agricultural demand. The human-induced reduction in streamflow in the JRB was primarily caused by soil and water conservation measures and water withdrawal (Shi, 2013; Zhao et al., 2013). From Table 8 , it can be observed that the large-scale soil conservation area expanded with time to prevent soil and water loss since the 1970s. As shown in Table 8, the amount of afforestation and level terrace land steadily increased since 1970 and that the amount of grass-planting land markedly increased since 1990 . As of the 2000s, newly increased soil and water conservation areas in the basin were composed of $2907 \mathrm{~km}^{2}$ of terrace land, $4773 \mathrm{~km}^{2}$ of afforestation land, $1146 \mathrm{~km}^{2}$ of grassland and $52 \mathrm{~km}^{2}$ of dammed land. These soil conservation practices intercept precipitation, change local characteristics, improve the infiltration rate of water flow, slow down or retain the streamflow, and consequently delay or even reduce streamflow. Additionally, during the past few decades, there were dramatic increases in the population and the irrigated area in the study area, which could have resulted in increased water withdrawal from the river. The evaluation of the individual effects on the hydrological regime still poses a challenge for hydrologists.

\section{Conclusions}

This paper investigated the impact of human activities and climate variability on streamflow using observed data and three methods (an elasticity-based method, a calibrated TOPMODEL, and a VIC model) for the JRB in China.

1. The variability of streamflow, precipitation, potential evaporation, and temperature in the JRB was analyzed. The annual precipitation and streamflow both showed a statistically decreasing trend, while the streamflow had a larger decrease, and the decrease in speed was higher since 1990. The potential evaporation presented an in- significant increasing trend; however, the temperature had a significant increasing trend.

2. The precipitation elasticity $\left(\varepsilon_{P}\right)$ and evapotranspiration elasticity $\left(\varepsilon_{E_{0}}\right)$ of streamflow for different periods were calculated using the Budyko formulation of $\mathrm{Fu}$. The results indicated that a $10 \%$ decrease in precipitation would result in a $14.8 \%$ drop in streamflow, while a $10 \%$ decrease in potential evapotranspiration would induce a $4.8 \%$ increase of streamflow.

3. Compared to the baseline period of 1960 to 1970 , streamflow in the JRB greatly decreased during 20012010. Climate variability and human activities impacts from the hydrological models were similar to those from the elasticity-based method.

4. The maximum contribution value of human activities appeared in 1981-1990 due to the effects of soil and water conservation measures and water withdrawal for industry and agricultural water demand, whereas climate variability made the greatest contributions to the streamflow reduction in 1991-2000. The contribution ratios of human activities and climate variability were 99 and $40.4 \%$ when averaged over the three methods.

Acknowledgements. This research was supported by the Natural Science Foundation of China (51190093) and Key Innovation Group of Science and Technology of Shaanxi (2012KCT-10). Sincere gratitude is extended to the editor and the anonymous reviewers for their professional comments and corrections.

Edited by: F. Tian

\section{References}

Arora, V. K.: The use of the aridity index to assess climate change effect on annual runoff, J. Hydrol., 265, 164-177, 2002.

Bao, Z., Zhang, J., Wang, G., Fu, G., He, R., Yan, X., Jin, J., Liu, Y., and Zhang, A.: Attribution for decreasing streamflow of the Haihe River basin, northern China: Climate variability or human activities, J. Hydrol., 460-461, 117-129, doi:10.1016/j.jhydrol.2012.06.054, 2012.

Beven, K. J. and Kirkby, M. J.: A physically based variable contributing area model of basin hydrology, Hydrological Sciences Bulletin, 24, 43-69, 1979.

Boston, T., Xia, J., and Zhu, Y.: Pre-processing rainfall data from multiple gauges to improve TOPMODEL simulation results in a large semi-arid region, Hydrol. Process., 18, 2313-2325, doi:10.1002/hyp.5530, 2004.

Chang, F.-J., Chang, L.-C., Kao, H.-S., and Wu, G.-R.: Assessing the effort of meteorological variables for evaporation estimation by self-organizing map neural network, J. Hydrol., 384, 118-129, 2010.

Chang, J.-X., Wang, Y., Istanbulluoglu, E., Bai, T., Huang, Q., Yang, D., and Huang, S.: Impact of climate change and human activities on runoff in the Weihe River Basin, China, Quatern. Int., 380 381, 169-179, 2015. 
Chen, J. and $\mathrm{Wu}, \mathrm{Y}$.: Advancing representation of hydrologic processes in the Soil and Water Assessment Tool (SWAT) through integration of the TOPographic MODEL (TOPMODEL) features, J. Hydrol., 420-421, 319-328, doi:10.1016/j.jhydrol.2011.12.022, 2012.

Chien, H., Yeh, P. J.-F., and Knouft, J. H.: Modeling the potential impacts of climate change on streamflow in agricultural watersheds of the Midwestern United States, J. Hydrol., 491, 73-88, doi:10.1016/j.jhydrol.2013.03.026, 2013.

Chiew, F. H. S.: Estimation of rainfall elasticity of streamflow in Australia, Hydrolog. Sci. J., 51, 613-625, 2006.

Destouni, G., Jaramillo, F., and Prieto, C.: Hydroclimatic shifts driven by human water use for food and energy production, Nat. Clim. Change., 3, 213-217, doi:10.1038/nclimate1719, 2013.

Donohue, R. J., Roderick, M. L., and McVicar, T. R.: On the importance of including vegetation dynamics in Budyko's hydrological model, Hydrol. Earth Syst. Sci., 11, 983-995, doi:10.5194/hess11-983-2007, 2007.

Donohue, R. J., Roderick, M. L., and McVicar, T. R.: Assessing the differences in sensitivities of runoff to changes in climatic conditions across a large basin, J. Hydrol., 406, 234-244, doi:10.1016/j.jhydrol.2011.07.003, 2011.

Dooge, J. C., Bruen, M., and Parmentier, B.: A simple model for estimating the sensitivity of runoff to long-term changes in precipitation without a change in vegetation, Adv. Water Resour., 23, 153-163, 1999.

Du, J. and Shi, C.: Effects of climate factors and human activities on runoff of the Weihe River in recent decades, Quatern. Int., 282, 58-65, 2012.

$\mathrm{Fu}$, B. P.: On the calculation of the evaporation from land surface, Chinese Journal of Atmospheric Sciences, 5, 23-31, 1981.

$\mathrm{Fu}, \mathrm{B}$. P.: On the calculation of evaporation from land surface in mountainous areas, Scientia Meteorologica Sinica, 6, 328-335, 1996.

Fu, G., Charles, S. P., and Chiew, F. S. H.: A two-parameter climate elasticity of streamflow index to assess climate change effects on annual streamflow, Water Resour. Res. 43, W11419, doi:10.1029/2007WR005890, 2007.

Furusho, C., Chancibault, K., and Andrieu, H.: Adapting the coupled hydrological model ISBA-TOPMODEL to the long-term hydrological cycles of suburban rivers: evaluation and sensitivity analysis, J. Hydrol., 485, 139-147, 2013.

Gao, H., Bohn, T. J., Podest, E., McDonald, K. C., and Lettenmaier, D. P.: On the causes of the shrinking of lake Chad, Environ. Res. Lett., 6, 034021, doi:10.1088/1748-9326/6/3/034021, 2011.

Gao, P., Geissen, V., Ritsema, C. J., Mu, X.-M., and Wang, F.: Impact of climate change and anthropogenic activities on stream flow and sediment discharge in the Wei River basin, China, Hydrol. Earth Syst. Sci., 17, 961-972, doi:10.5194/hess-17-9612013, 2013.

Grimson, R., Montroull, N., Saurral, R., Vasquez, P., and Camilloni, I.: Hydrological modelling of the Iberá Wetlands in southeastern South America, J. Hydrol., 503, 47-54, doi:10.1016/j.jhydrol.2013.08.042, 2013.

Gumindoga, W., Rientjes, T. H. M., Haile, A. T., and Dube, T.: Predicting streamflow for land cover changes in the Upper Gilgel Abay River Basin, Ethiopia: a TOPMODEL based approach, Phys. Chem. Earth, 76-78, 3-15, 2014.
Hamed, K. H.: Trend detection in hydrologic data: the MannKendall trend test under the scaling hypothesis, J. Hydrol. 349, 350-363, 2008.

Li, D., Pan, M, Cong, Z., and Wood, E.: Vegetation control on water and energy balance within the Budyko framework, Water Resour. Res. 49, 969-976, doi:10.1002/wrcr.20107, 2013.

Li, H., Zhang, Y., Vaze, J., and Wang, B.: Separating effects of vegetation change and climate variability using hydrological modelling and sensitivity-based approaches, J. Hydrol., 420-421, 403-418, 2012.

Liang, X., Lettenmaier, D. P., Wood, E. F., and Burges, S. J.: A simple hydrologically based model of land surface water and energy fluxes for GSMs, J. Geophys. Res., 99, 415-428, 1994.

Lin, S.-H., Liu, C.-M., Huang, W.-C., Lin, S.-S., Yen, T.-H., Wang, H.-R., Kuo, J.-T., and Lee, Y. C.: Developing a yearly warning index to assess the climatic impact on the water resources of Taiwan, a complex-terrain island, J. Hydrol., 390, 13-22, 2010.

Liu, H., Tian, F., Hu, H. C., Hu, H. P., and Sivapalan, M.: Soil moisture controls on patterns of grass green-up in Inner Mongolia: an index based approach, Hydrol. Earth Syst. Sci., 17, 805-815, doi:10.5194/hess-17-805-2013, 2013.

Liu, Q., Yang, Z., Cui, B., and Sun, T.: Temporal trends of hydroclimatic variables and runoff response to climatic variability and vegetation changes in the Yiluo River basin, China, Hydrol. Process., 23, 3030-3039, 2009.

Ma, H., Yang, D., Tan, S. K., Gao, B., and Fu, Q.: Impact of climate variability and human activity on streamflow decrease in the Miyun Reservoir catchment, J. Hydrol., 389, 317-324, 2010.

Milly, P. C. D.: An analytic solution of the stochastic storage problem applicable to soil water, Water Resource Res., 29, 37553758, 1993.

Milly, P. C. D. and Dunne, K. A.: Macroscale water fluxes 2. Water and energy supply control of their inter-annual variability, Water Resour. Res., 38, 241-249, 2002.

Notebaert, B., Verstraeten, G., Ward, P., Renssen, H., and Van Rompaey, A.: Modeling the sensitivity of sediment and water runoff dynamics to Holocene climate and land use changes at the catchment scale, Geomorphology, 126, 18-31, 2011.

Peng D. Z. and Xu, Z. X.: Simulating the impact of climate change on streamflow in the Tarim River basin by using a modified semidistributed monthly water balance model, Hydrol. Process. 24, 209-216, doi:10.1002/hyp.7485, 2010.

Petchprayoon, P., Blanken, P. D., Ekkawatpanit, C., and Husseinc, K.: Hydrological impacts of land use/land cover change in a large river basin in central-northern Thailand, Int. J. Climatol., 30, 1917-1930, 2010.

Potter, N. J. and Chiew, F. H. S.: An investigation into changes in climate characteristics causing the recent very low runoff in the southern Murray- Darling Basin using rainfall-runoff models, Water Resour. Res., 47, W00G10, doi:10.1029/2010WR010333, 2011.

Renner, M., Seppelt, R., and Bernhofer, C.: Evaluation of waterenergy balance frameworks to predict the sensitivity of streamflow to climate change, Hydrol. Earth Syst. Sci., 16, 1419-1433, doi:10.5194/hess-16-1419-2012, 2012.

Roderick, M. L. and Farquhar, G. D.: A simple framework for relating variations in runoff to variations in climatic conditions and catchment properties, Water Resour. Res., 47, W00G07, doi:10.1029/2010WR009826, 2011. 
Roudier, P., Ducharne, A., and Feyen, L.: Climate change impacts on runoff in West Africa: a review, Hydrol. Earth Syst. Sci., 18, 2789-2801, doi:10.5194/hess-18-2789-2014, 2014.

Sankarasubramanian, A., Vogel, R. M., and Limbrunner, J. F.: Climate elasticity of streamflow in the United States, Water Resour. Res., 37, 1771-1781, 2001.

Scanlon, B. R., Jolly, I., Sophocleous, M., and Zhang, L.: Global impacts of conversion from natural to agricultural ecosystem on water resources: quantity versus quality, Water Resour. Res., 43, W03437, doi:10.1029/2006WR005486, 2007.

Schaake, J. C.: From climate to flow, in: Climate Change and U.S. Water Resources, edited by: Waggoner, P. E., John Wiley, New York, USA, 177-206, 1990.

Seibert, J., Bishop, K. H., and Nyberg, L.: A test of TOPMODEL's ability to predict spatially distributed groundwater levels, Hydrol. Process. 11, 1131-1144, 1997.

Shi, C., Zhou, Y., Fan, X., and Shao, W.: A study on the annual runoff change and its relationship with water and soil conservation practices and climate change in the middle Yellow River basin, Catena, 100, 31-41, 2013.

$\mathrm{Su}, \mathrm{F}$. and Xie, Z.: A model for assessing effects of climate change on runoff of China, Prog. Nat. Sci., 13, 701-707, 2003.

Sun, Y., Tian, F., Yang, L, and Hu, H.: Exploring the spatial variability of contributions from climate variation and change in catchment properties to streamflow decrease in a mesoscale basin by three different methods, J. Hydrol., 508, 170-180, 2014.

Tang, Y., Tang, Q., Tian, F., Zhang, Z., and Liu, G.: Responses of natural runoff to recent climatic variations in the Yellow River basin, China, Hydrol. Earth Syst. Sci., 17, 4471-4480, doi:10.5194/hess-17-4471-2013, 2013.

Teng, J., Vaze, J., Chiew, F. H. S., Wang, B., and Perraud, J. M.: Estimating the relative uncertainties sourced from GCMs and hydrological models in modelling climate change impact on runoff, J. Hydrometeorol., 13, 122-139, 2012.

Tesfa, T. K., Li, H.-Y., Leung, L. R., Huang, M., Ke, Y., Sun, Y., and Liu, Y.: A subbasin-based framework to represent land surface processes in an Earth system model, Geosci. Model Dev., 7, $947-$ 963, doi:10.5194/gmd-7-947-2014, 2014.

Tomer, M. D. and Schilling, K. E.: A simple approach to distinguish land-use and climate-change effects on watershed hydrology, J. Hydrol., 376, 24-33, 2009.

Tuteja, N. K., Vaze, J., Teng, J., and Mutendeudzi, M.: Partitioning the effects of pine plantations and climate variability on runoff from a large catchment in southeastern Australia, Water Resour. Res., 43, 199-212, doi:10.1029/2006WR005016, 2007.

Van Lill, W. S., Kruger, F. J., and Van Wyk, D. B.: The effect of afforestation with Eucalyptus Grandis Hill ex Maiden and Pinus Patula Schlecht. et Cham. On streamflow from experimental catchments at Mokobulaan, Transvaal, J. Hydrol., 48, 107-118, 1980 .

Wang, D. and Hejazi, M.: Quantifying the relative contribution of the climate and direct human impacts on mean annual streamflow in the contiguous United States, Water Resour. Res., 47, W00J12, doi:10.1029/2001wr000760, 2011.

Wang, D., Hagen, S. C., and Alizad, K.: Climate change impact and uncertainty analysis of extreme rainfall events in the Apalachicola River basin, Florida, J. Hydrol., 480, 125-135, 2013.
Wang, D. B., Zhao, J. S., Tang, Y., and Sivapalan, M.: A thermodynamic interpretation of Budyko and L'vovich formulations of annual water balance: Proportionality Hypothesis and maximum entropy production, Water Resour. Res., 51, 3007-3016, doi:10.1002/2014WR016857, 2015

Wang, J. H., Hong, Y., Gourley, J., Adhikari, P., Li, L., and Su, F. G.: Quantitative assessment of climate change and human impacts on long-term hydrologic response: a case study in a sub-basin of the Yellow River. China, Int. J. Climatol., 30, 2130-2137, doi:10.1002/joc.2023, 2010.

Ward, P. J., van Balen, R. T., Verstraeten, G., Renssen, H., and Vandenberghe, J.: The impact of land use and climate change on late Holocene and future suspended sediment yield of the Meuse catchment, Geomorphology, 103, 389-400, 2009.

Willmott, C. J. and Feddema, J. J.: A more rational climatic moisture index, Prof. Geogr., 44, 84-88, doi:10.1111/j.00330124.1992.00084.x, 1992.

Willmott, C. J., Robeson, S. M., and Feddema, J. J.: Influence of spatially variable instrument networks on climatic averages, Geophys. Res. Lett., 18, 2249-2251, 1991.

Xiong, L. and Guo, S.: Effects of the catchment runoff coefficient on the performance of TOPMODEL in rainfall-runoff modelling, Hydrol. Process., 8, 1823-1836, doi:10.1002/hyp.1449, 2004.

Xu, X., Yang, H., Yang, D., and Ma, H.: Assessing the impacts of climate variability and human activities on annual runoff in the Luan River Basin, China, Hydrol. Res., 44, 940-952, doi:10.2166/nh.2013.144, 2013.

Yang, D., Li, C., Hu, H., Lei, Z., Yang, S., Kusuda, T., Koike, T., and Musiake, K.: Analysis of water resources variability in the Yellow River of China during the last half century using historical data[J], Water Resour. Res., 40, 308-322, doi:10.1029/2003WR002763, 2004.

Yang, H., Yang, D., Lei, Z., and Sun, F., New analytical derivation of the mean annual water-energy balance equation, Water Resour. Res., 44, W034103, doi:10.1029/2007WR006135, 2008.

Zhan, C. S., Jiang, S. S., Sun, F. B., Jia, Y. W., Niu, C. W., and Yue, W. F.: Quantitative contribution of climate change and human activities to runoff changes in the Wei River basin, China, Hydrol. Earth Syst. Sci., 18, 3069-3077, doi:10.5194/hess-183069-2014, 2014.

Zhang, C., Peng, Y., Chu, J., Shoemaker, C. A., and Zhang, A.: Integrated hydrological modelling of small- and medium-sized water storages with application to the upper Fengman Reservoir Basin of China, Hydrol. Earth Syst. Sci., 16, 4033-4047, doi:10.5194/hess-16-4033-2012, 2012.

Zhang, L., Dawes, W. R., and Walker, G. R.: Response of mean annual evapotranspiration to vegetation changes at catchment scale, Water Resour. Res., 37, 701-708, 2001.

Zhang, X., Zhang, L., Zhao, J., Rustomji, P., and Hairsine, P.: Responses of streamflow to changes in climate and land use/cover in the Loess Plateau, China, Water Resour. Res., 44, W00A07, doi:10.1029/2007WR006711, 2008.

Zhao, G., Mu, X., Tian, P., Wang, F., and Gao, P.: Climate changes and their impacts on water resources in semiarid regions: a case study of the Wei River basin, China, Hydrol. Process. 27, 38523863, 2013. 